\title{
Artikel Pengabdian
}

\section{Edukasi Kelompok Prolanis Dalam Pencegahan Covid 19}

\author{
Shahrul Rahman', Elman Boy ${ }^{2}$ \\ ${ }^{1}$ Departemen IImu Penyakit Dalam, Fakultas Kedokteran; Universitas Muhammadiyah Sumatera Utara \\ ${ }^{2}$ Departemen IImu Kesehatan Masyarakat; Fakultas Kedokteran' Universitas Muhammadiyah Sumatera Utara \\ email: elmanboy@umsu.ac.id
}

\begin{abstract}
Abstrak
Lansia merupakan satu kelompok prioritas dalam upaya pencegahan Covid 19, karena kelompok pada umumnya memiliki komorbid pernyakit seperti hipertensi dan diabetes melitus. Peserta Program Pengelolaan Penyakit Kronis (Prolanis) yang umumnya merupakan lansia yang telah terdaftar di fasilitas kesehatan layanan primer (Fasyankes) seperti Puskesmas dan klinik. Klinik Iman di Martubung merupakan salah satu Fasyankes yang mengelola peserta Prolanis. Upaya pencegahan Covid 19 diperlukan bagi kelompok lansia yang tergabung dalam Prolanis. Kegiatan ini merupakan Program Kemitraan Pengembangan Muhammadiyah (PKPM) yang diselenggarakan Fakultas Kedokteran UMSU. Strategi pelaksanaan PKPM ini terdiri dari 3 langkah yaitu: persiapan, pelaksanaan dan evaluasi. Hasil kegiatan ini menunjukkan bahwa edukasi pencegahan Covid 19 pada lansia sangat diperlukan.
\end{abstract}

Kata Kunci: Covid-19, Edukasi, Prolanis

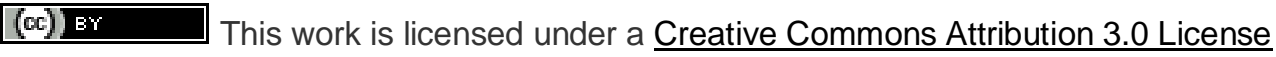

\section{PENDAHULUAN}

Jumlah Lansia meningkat tidak saja di Indonesia tapi juga bagi dunia. Indonesia sedang berjuang meningkatkan umur harapan hidup sembari meningkatkan kualitas harapan hidup. Fakta yang terjadi saat ini umur harapan hidup yang semakin meningkat tetapi umur kualitas hidup semakin menurun. Upaya untuk meningkatkan kualitas hidup lansia sangat terkait dengan pemenuhan pelayanan kesehatan bagi mereka termasuk pemenuhan upaya promotif preventif. Semakin bertambah usia seseorang maka kualitas hidupnya mengalami berbagai tantangan dan permasalahan. ${ }^{1}$

Peran keluarga agar lansia tetap dalam kondisi yang optimal sangat penting dalam membentuk kemandirian lansia. Data menunjukkan bahwa lansia yang mandiri masih sebesar $74 \%$, sedangkan yang mengalami tergantung berat sebesar $22 \%$. Kemandirian lansia akan memberikan berbagai keuntungan bagi keluarga. Lansia sehat mempunyai fungsi kognitif yang baik akan mempunyai fungsi mental dan spiritual yang baik akan mampu melakukan gaya hidup yang sehat serta aktif di dalam kehidupan masyarakat. $^{2}$ Pemberdayaan lansia yang ada di wilayah kerja Puskesmas atau klinik bukan hanya memberikan pelayanan kepada lansia yang dalam kondisi sakit, namun turut memberikan dukungan pemeliharaan dan perawatan Kesehatan kepada pihak keluarga. ${ }^{3}$ 
e-ISSN 2716-0254

Masyarakat dan pemberi pelayanan kesehatan bagi masyarakat yakni pelayanan kesehatan primer maupun di upaya pelayanan kesehatan rujukan sangat berharap bahwa Pandemi Covid 19 ini dapat segera berakhir. Kepatuhan terhadap peraturan protokol kesehatan diharapkan mampu mengantarkan masyarakat ke dalam kehidupan normal kembali dengan lebih baik. Prinsip protokol kesehatan dalam menuju kehidupan normal yang baru atau new normal perlu disosialisasikan dan senantiasa terus diingatkan tidak hanya kepada para lansia tapi juga pada para keluarga. Kebiasaan yang baik yaitu antara lain melakukan cuci tangan dengan sabun jika tidak memungkinkan dalam kondisi tertentu, bisa menggunakan hand sanitizer, kemudian yang kedua adalah membiasakan menggunakan masker baik di dalam rumah maupun di luar rumah, di dalam rumah bagi keluarga yang mempunyai potensi sakit atau berpotensi untuk menjadi sakit, lalu yang berikutnya adalah menjaga jarak sesama anggota keluarga apalagi kalau lansia berada di luar rumah. ${ }^{4}$ Bagi lansia mempunyai komorbid tentunya perlu diingatkan untuk meminum obat tepat waktu, jangan sampai mengulang-ulang minum obat sehingga terjadi overdosis serta selalu menjaga lingkungan rumah dan juga lingkungan yang ada di masyarakat tetap bersih sehat. ${ }^{5}$

Di Indonesia prevalensi penyakit tidak menular (PTM) dan penyakit menular (PM) angkanya masih cukup tinggi. ${ }^{6}$ Prevalensi penyakit infeksi saluran nafas pada lansia angkanya cukup tinggi. Lansia sangat rentan menderita penurunan sistem imunitas tubuh dan juga cenderung mempunyai satu atau lebih penyakit yang menjadi komorbid sehingga lebih berisiko terpapar Covid 19 dan angka kematiannya pun cukup tinggi. Prevalensi hipertensi memberi kontribusi yang tertinggi pada lansia diikuti diabetes, penyakit jantung kemudian penyakit paru obstruktif kronik (PPOK). Seluruh Komorbid ini akan memperburuk kondisi para lansia jika mereka terjangkit Covid 19. ${ }^{5}$

Perguruan tinggi memiliki kontribusi yang besar untuk melakukan upaya pencegahan penyakit Covid 19 yang saat ini tengah menjadi pandemi. Kolaborasi antara perguruan tinggi dengan pemerintah dan swasta dalam penanganan Covid 19 sangat diperlukan. ${ }^{7}$ Fakultas Kedokteran Universitas Muhammadiyah Sumatera Utara (FK UMSU). UMSU tengah menggulirkan hibah pengabdian masyarakat dengan berbagai skema, antara lain Program Kemitraan Pengembangan Muhammadiyah (PKPM). PKPM ini digunakan untuk memberikan pendampingan dan penguatan mitra-mitra Fakultas Kedokteran UMSU khususnya dalam kegiatan promotif dan preventif Covid 19.

\section{METODE}

PKPM ini dilakukan dalam 3 tahap kegiatan. Tahap pertama adalah tahap perencanaan, tahap kedua adalah tahap pelaksanaan dan tahap ketiga adalah tahap evaluasi. Tahap pertama dilakukan dengan mempersiapkan perencanaan kegiatan yang disusun dalam satu proposal kegiatan yang lengkap sesuai dengan peraturan yang telah di tetapkan oleh Lembaga Penelitian dan Pengabdian Masyarakat (LPPM) UMSU. Pada tahap ini, proposal yang disetujui untuk di danai oleh UMSU melalui surat keputusan rektor akan mulai mempersiapkan perangkat pengabdian masyarakat, yakni antara lain komunikasi dengan mitra dan administrasi dokumentasi kegiatan. Mitra diminta untuk menyiapkan peserta pengabdian berupa anggota kelompok Prolanis yang terdaftar di Klinik Iman yang berada di Jalan Pancing I No. 17 Martubung. Pelaksana 
menyiapkan lembar administrasi berupa registrasi peserta pengabdian dan hadiah yang pantas untuk diberikan bagi peserta yang mengikuti pengabdian masyarakat secara tuntas. Pelaksana juga menyediakan media presentasi yang sesuai untuk tatap muka serta kuesioner pre dan post tes.

Pada tahap pelaksanaan peserta yang hadir mengisi lembar registrasi kemudian masuk keruang pertemuan yang telah di tetapkan. Setiap peserta kemudian mengisi lembar pre tes yang telah disiapkan oleh tim sebelum presentasi dari pemakalah di mulai. Saat pemakalah menyampaikan presentasi mengenai Covidmelalui layar televisi yang telah disiapkan maka seluruh peserta dikondisikan untuk bisa menyaksikan dengan seksama. Setelah presentasi pemakalah selesai, peserta dipersilahkan untuk mengajukan pertanyaan terkait dengan pencegahan Covid 19. Setelah itu, peserta diminta untuk mengisi lembar post tes sesuai dengan jadwal waktu yang telah di tentukan.

Pada tahap evaluasi, seluruh kuesioner yang telah terkumpul di cek kelengkapan data dan isinya lalu dilanjutkan dengan tahap input data ke dalam aplikasi kemudian di analisis. Data diinput dan dianalisis menggunakan aplikasi mikrosoft excel. Data yang sudah selesai di cleaning dan editing akan di sampaikan pada laporan hasil serta digunakan untuk kepentingan laporan penelitian, penulisan artikel ilmiah dan publikasi media massa.

\section{HASIL}

Kegiatan ini diikuti oleh tim pelaksana pengabdian masyarakat, mahasiswa sebagai moderator dan tenaga Pendidikan sebagai administrator serta 38 peserta Prolanis. Acara ini dilaksanakan pada hari Ahad, 21 Juni 2020 di Klinik Iman di Jalan
e-ISSN 2716-0254

Pancing I No. 17 Martubung Kota Medan. Adapun distribusi karakteristik pasien yang mengikuti kegiatan berdasarkan usia tampak seperti pada gambar 1. Berdasarkan usia maka peserta yang paling tua adalah berusia 75 tahun sebanyak 1 orang, sedangkan yang termuda sebanyak 46 tahun sebanyak 2 orang. Rata-rata usia peserta adalah 62,8 tahun dengan nilai median sebesar 63,5 tahun dan modus sebesar 66 tahun. Distribusi peserta Prolanis yang mengikuti kegiatan pengabdian masyarakat berdasarkan jenis kelamin terdapat pada gambar 2.

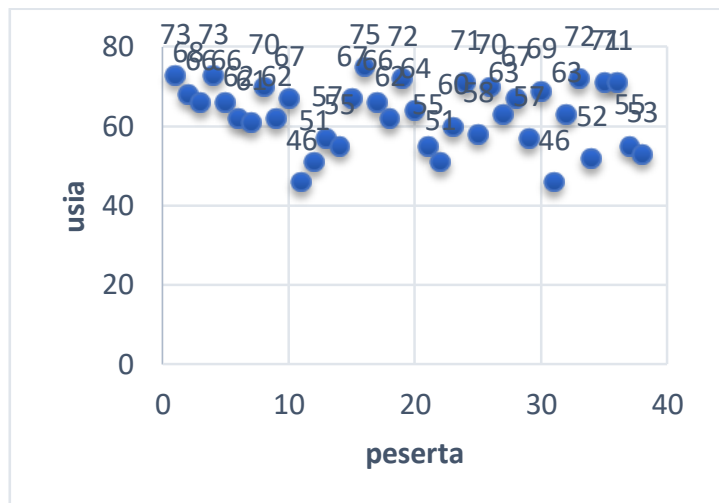
Gambar 1. Distribusi Peserta Prolanis yang Mengikuti Kegiatan Pengabdian Masyarakat Berdasarkan Usia

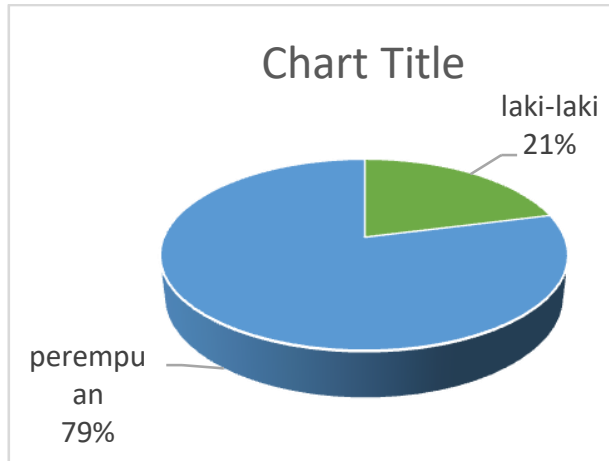

Gambar 2. Distribusi Peserta Prolanis yang Mengikuti Kegiatan Pengabdian Masyarakat Berdasarkan Jenis Kelamin

Berdasarkan gambar 1 di atas, jenis kelamin, tampak perempuan lebih banyak mengikuti kegiatan ini yakni sebesar $79 \%$ dibandingkan laki-laki yang hanya sebesar $21 \%$. Distribusi peserta Prolanis yang 
mengikuti kegiatan pengabdian masyarakat berdasarkan penyakit yang diderita terdapat pada gambar 3 .

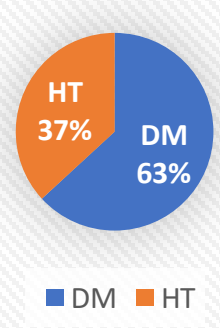

\section{Gambar 3. Distribusi Peserta Prolanis yang Mengikuti Kegiatan Pengabdian Masyarakat Berdasarkan Penyakit Yang Diderita}

Berdasarkan gambar 3 di atas, berdasarkan jenis penyakit tampak diabetes mendominasi penyakit yang diderita para peserta kegiatan ini yakni sebesar $63 \%$ dibandingkan hipertensi yang hanya sebesar 37\%. Distribusi peserta Prolanis yang mengikuti kegiatan pengabdian masyarakat berdasarkan hasil pre tes dan post tes terdapat pada gambar 4.

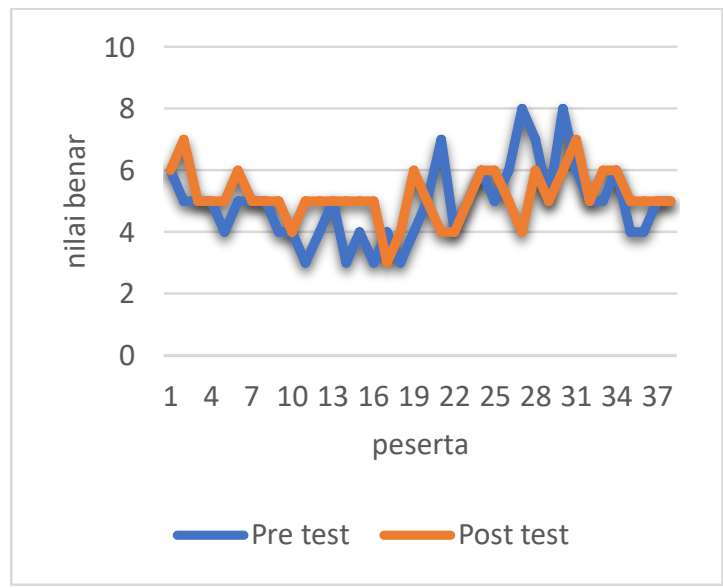

Gambar 4. Distribusi Peserta Prolanis yang Mengikuti Kegiatan Pengabdian Masyarakat Berdasarkan Hasil Pre Tes Dan Post Tes

Berdasarkan gambar 4 di atas, hasil pre tes dan post tes, tampak rata-rata hasil pre test adalah sebesar $49 \%$ sedangkan rata-rata hasil post tes setelah diberi edukasi meningkat menjadi sebesar $51 \%$.

\section{DISKUSI}

e-ISSN 2716-0254

Karakteristik dan distribusi penderita Covid 19 yang terjadi di Wuhan, Cina, lansia yang berusia di atas 60 tahun merupakan penderita yang paling berisiko mengalami gejala berat $(46,9 \%)$ dan perempuan paling banyak sebagai korban (51 \%) serta hipertensi yang menjadi komorbid paling banyak $(40,8 \%)$ dan diikuti diabetes sebesar $16 \% .^{8}$ Data pengabdian masyarakat yang dilaksanakan menunjukkan perbedaan karakteristik lansia yang tidak jauh berbeda, dimana peserta Prolanis berusia rata-rata 66 tahun dan didominasi perempuan sebesar $79 \%$, namun sedikit berbeda pada komorbid yang terjadi. Pada kegiatan ini yang menjadi komorbid terbesar adalah diabetes sebesar 63\% sedangkan hipertensi sebesar 37\%. Data ini menunjukkan Tindakan preventif sangat diperlukan agar lansia tidak terinfeksi Covid 19 yang akan menyebabkan morbiditas dan mortalitas.

Langkah-langkah preventif untuk mengendalikan penyebaran pandemik Covid 19 pada lansia dipengaruhi oleh tingkat pengetahuan, sikap dan tindakan mereka. Ketaatan seseorang dipengaruhi pengetahuan, sikap dan tindakan mereka. Keberhasilan Cina dalam mengendalikan Covid 19 tidak terlepas dari ketaatan penduduknya terhadap regulasi yang ditetapkan oleh pemerintah. Dari penelitian mengenai perilaku masyarakat terhadap Covid 19 yang dilakukan di Hubei, Cina tergambar betapa warga Tiongkok memiliki pengetahuan yang sangat baik terhdap karakteristik klinis dan upaya pencegahan Covid 19. Pengetahuan masyarakat Cina tersebut diikuti dengan sikap mereka yang tidak abai terhadap regulasi yang telah ditetapkan pemerintah setempat. Mereka juga percaya bahwa mereka dapat berhasil memenangkan pertempuran 
melawan Covid 19 dan hal ini mereka buktikan. Ketaatan warga Tiongkok untuk itu begitu besar terhadap aturan, $98 \%$ responden yang ikut dalam penelitian mengaku senantiasa menggunakan masker saat keluar rumah. Sikap optimistik seperti ini diakui Cina sangat diperlukan dalam memerangi Covid 19. ${ }^{9}$

Situasi yang hampir sama dengan Indonesia terjadi di Bangladesh, sebuah negara dengan ekonomi rendah dalam menghadapi Covid 19. Sebuah penelitian mengenai perilaku di Bangladesh telah dilakukan untuk mengendalikan penyebaran COVID 19. Studi crosssectional berbasis online yang dilakukan pada Maret hingga April 2020 yang melibatkan penduduk Bangladesh berusia 12-64 tahun menunjukkan anomali informasi dimana meskipun Mayoritas $(96,7 \%)$ dari peserta mengaku setuju Covid 19 adalah penyakit berbahaya namun hanya $48,3 \%$ peserta yang memiliki pengetahuan yang akurat tentang Covid 19, sedangkan praktik pencegahan hanya dilaksanakan sebesar $55,1 \%{ }^{10}$ Virus ini dikonfirmasi telah menyebar ke Bangladesh pada Maret 2020. Tiga kasus pertama yang diketahui dilaporkan pada 8 Maret 2020 oleh lembaga epidemiologi negara itu. ${ }^{11}$ Infeksi tetap rendah sampai akhir Maret tetapi mengalami kenaikan tajam pada bulan April. ${ }^{12}$ Dalam minggu yang terakhir bulan April 2020, kasus-kasus baru di Bangladesh tumbuh menjadi yang tertinggi di Asia, bahkan di atas Indonesia. $^{13}$

Pengabdian masyarakat yang kami lakukan ini juga menunjukkan pengetahuan peserta yang rendah. Dari hasil pre tes dan post tes, tampak ratarata hasil pre test adalah sebesar $49 \%$ sedangkan rata-rata hasil post tes setelah diberi edukasi hanya meningkat tipis menjadi sebesar $51 \%$. Mungkin usia menjadi faktor utama. Covid 19, pandemi
e-ISSN 2716-0254

yang belum pernah terjadi sebelumnya telah membuat dunia mengalami perubahan yang sangat besar. Kecemasan, stres, perubahan suasana hati, panik, marah, dan depresi telah diamati terjadi pada masyarakat terutama di kalangan lansia. Kurungan selama di rumah saja dan pembatasan jarak sosial telah menyebabkan lansia menjadi lebih rentan terhadap beberapa penyakit fisik seperti hipertensi, diabetes, penyakit pernapasan, kelemahan, risiko jatuh dan demensia, dan perubahan status mental seperti ketakutan, gangguan kecemasan, gangguan psikosomatik, gangguan kognitif, atau penurunan dan bahkan mengarah pada gangguan pasca-trauma. Mendapatkan kembali kesehatan fisik dan mental dapat dilakukan melalui intervensi fasilitasi sosial, psikoterapi, penyediaan perawatan sosial pengembangan keterampilan dan rekreasi. Cinta kasih, perhatian, dan kepedulian terhadap lansia oleh orang lain dan keluarga secara nyata dapat mengatasi banyak ketegangan fisik dan mental. ${ }^{14}$

\section{KESIMPULAN}

Langkah-langkah preventif untuk mengendalikan penyebaran pandemik Covid 19 pada lansia sangat dipengaruhi pengetahuan, sikap dan tindakan mereka. Intervensi dan fasilitasi dari berbagai pihak di bidang sosial, psikoterapi, perawatan kesehatan sangat diperlukan. Cinta kasih, perhatian, dan kepedulian terhadap lansia oleh orang lain dan keluarga dapat mengatasi banyak ketegangan fisik dan mental mereka.

\section{UCAPAN TERIMA KASIH/ ACKNOWLEDGEMENT}

Ucapan terima kasih ditujukan kepada Universitas Muhammadiyah Sumatera Utara yang memberikan hibah dana pengabdian dan kepada Klinik Iman yang 
telah memberikan bantuan terhadap persiapan, termasuk teknis, dan dukungan untuk kegiatan pengabdian masyarakat ini.

\section{REFERENSI}

1. World Health Organization. Health situation and trend assessment: elderly population. World Heal Organ. 2019;

2. Kaur $H$, Kaur $H$, Venkateashan $M$. Factors determining family support and quality of life of elderly population. Int $\mathrm{J}$ Med Sci Public Heal. 2015;

3. Kadar KS, Francis K, Sellick K. Ageing in Indonesia - Health Status and Challenges for the Future. Ageing International. 2013.

4. Yan Z. Unprecedented pandemic, unprecedented shift, and unprecedented opportunity. Hum Behav Emerg Technol. 2020;

5. Wang X, Fang X, Cai Z, Wu X, Gao X, Min J, et al. Comorbid Chronic Diseases and Acute Organ Injuries Are Strongly Correlated with Disease Severity and Mortality among Covid 19 Patients: A Systemic Review and MetaAnalysis. Research. 2020;

6. Rodriguez-Fernandez $\mathrm{R}, \mathrm{Ng} \mathrm{N}$, Susilo D, Prawira J, Bangs MJ, Amiya RM. The double burden of disease among mining workers in Papua, Indonesia: At the crossroads between Old and New health paradigms. BMC Public Health. 2016;

7. Moradian N, Ochs HD, Sedikies C, Hamblin MR, Camargo CA, Martinez $J A$, et al. The urgent need for
e-ISSN 2716-0254

integrated science to fight Covid 19 pandemic and beyond. Journal of Translational Medicine. 2020.

8. Wang L, He W, Yu X, Hu D, Bao M, Liu $\mathrm{H}$, et al. Coronavirus disease 2019 in elderly patients: Characteristics and prognostic factors based on 4-week follow-up. J Infect. 2020;

9. Zhong BL, Luo W, Li HM, Zhang QQ, Liu XG, Li WT, et al. Knowledge, attitudes, and practices towards Covid 19 among chinese residents during the rapid rise period of the Covid 19 outbreak: A quick online crosssectional survey. Int J Biol Sci. 2020;

10. Ferdous MZ, Islam MS, Sikder MT, Mosaddek ASM, Zegarra-Valdivia JA, Gozal D. Knowledge, attitude, and practice regarding Covid 19 outbreak in Bangladeshi people: An online-based cross-sectional study. medRxiv. 2020;

11. Anwar S, Nasrullah M, Hosen MJ. Covid 19 and Bangladesh: Challenges and How to Address Them. Front Public Heal. 2020;

12. Shammi M, Bodrud-Doza M, Towfiqul Islam ARM, Rahman MM. Covid 19 Pandemic, Socioeconomic Crisis and Human Stress in Resource-Limited Settings: A Case from Bangladesh. Heliyon. 2020;

13. Rahaman Khan MH, Hossain A. Covid 19 Outbreak Situations in Bangladesh: An Empirical Analysis. medRxiv. 2020.

14. Mathew J, TJ V, Jose S, E.F R, K.J S. Maintaining Physical And Mental Health Among Elders During Covid 19. UGC Care J. 2020; 